\title{
Thinking through affect: Inuit knowledge on the tundra and in global environmental politics
}

\author{
Noor Johnson ${ }^{1}$ \\ Brown University, USA
}

\begin{abstract}
Inuit residents of the Canadian Arctic balance a commitment to the land and to land-based traditions with full engagement in governance across different scales of decision-making. In this article, I suggest that thinking with and through 'affect' offers a promising approach to conceptualizing the dynamic role of Inuit knowledge across these different scales. Food sharing in remote Inuit settlements tangibly demonstrates the affective dimensions of Inuit knowledge, reflecting practices rooted in social and ethical relations with land, animals, and human community. Affect also informs the role of Inuit knowledge in international environmental negotiations. I explore this relationship in the work of the Inuit Circumpolar Council (ICC), an organization that advocated for a ban on persistent organic pollutants (POP) in the negotiations leading up to the Stockholm Convention. Facilitated by the gift of an Inuit carving, ICC shared a moral and ethical perspective that helped connect negotiators to the physical harms caused by pollutants. Drawing on the philosophy of former ICC Chair Sheila Watt-Cloutier and the non-capitalist framework of J.K. Gibson-Graham (2006), I examine the role this gift played in the POPs negotiations. I conclude that thinking through affect offers new ways of conceptualizing the emergent possibilities of environmental politics and practice.
\end{abstract}

Keywords: Indigenous knowledge, persistent organic pollutants, Stockholm Convention, environmental politics, the gift, food sharing, Gibson-Graham.

\section{Résumé}

Les résidents inuits de l'Arctique canadien équilibrer leur attachement à la terre et aux traditions terrestres, avec la pleine participation à la gouvernance multi-scalaire. Dans cet article, je suggère que penser avec et à travers le concept de «affect» offre une approche prometteuse pour conceptualiser le rôle dynamique des connaissances des Inuits à travers ces différentes échelles. Le partage de la nourriture dans les collectivités inuites éloignées démontre concrètement les dimensions affectives de savoir inuit, reflétant les pratiques ancrées dans les relations sociales et éthiques avec la terre, les animaux, et de la communauté humaine. «Affect» informe également le rôle des connaissances des Inuits dans les négociations internationales sur l'environnement. J'explore cette relation dans le travail du Conseil Circumpolaire Inuit (ICC), une organisation qui a plaidé pour une interdiction sur les polluants organiques persistants (POP) dans les négociations menant à la Convention de Stockholm. Animé par le don d'une sculpture inuite, la ICC a partagé un point de vue moral et éthique qui a contribué à relier les négociateurs pour les dommages physiques causés par les polluants. S'appuyant sur la philosophie de l'ancien président de la ICC Sheila Watt-Cloutier et le cadre non-capitaliste de J.K.Gibson-Graham (2006), j'examine le rôle joué dans ce cadeau négociations sur les POP. Je conclus que réfléchir à «affect» offre de nouvelles façons de conceptualiser les possibilités émergentes de la politique et des pratiques environnementales.

Mots-clés: les connaissances autochtones, les polluants organiques persistants, la Convention de Stockholm, la politique de l'environnement, le don, le partage de la nourriture, Gibson-Graham.

\section{Resumen}

Los residentes Inuit del Ártico canadiense equilibran un compromiso a la tierra y a las tradiciones basadas-enla-tierra con un total compromiso en gobernanza a través de diferentes escalas de toma de decisión. En este artículo, sugiero que pensar con y a través del afecto ofrece una aproximación prometedora para conceptualizar el papel dinámico del conocimiento Inuit a través de estas diferentes escalas. Compartir la

\footnotetext{
${ }^{1}$ Dr. Noor Johnson, Voss Postdoctoral Fellow, Environmental Change Initiative, Brown University, Providence RI 02912, USA. Email: noor.johnson "at" gmail.com. I am grateful for research support from the Social Sciences and Humanities Research Council of Canada and the National Science Foundation. This is the third paper in Burke, B.J. and B.W. Shear (eds.) 2014. "Non-capitalist political ecologies", special section of the Journal of Political Ecology 21: 127-221.
} 
comida en asentamientos remotos Inuit tangiblemente demuestra las dimensiones afectivas del conocimiento Inuit, reflejando practicas enraizadas en relaciones sociales y éticas con la tierra, los animales, y la comunidad humana. El afecto también informa el papel del conocimiento Inuit en negociaciones ambientales internacionales. Exploro esta relación en el trabajo del Inuit Circumpolar Council (ICC), una organización que abogó por la prohibición de contaminantes orgánicos persistentes (COP) en las negociaciones llevadas a cabo en la Convención de Estocolmo. Facilitado por el regalo de un Inuit tallado, ICC compartió una perspectiva ética y moral que ayudó a conectar a los negociadores con los daños físicos causados por los contaminantes. Basado en la filosofía de de la antigua presidenta del ICC Sheila Watt-Cloutier y el marco nocapitalista de J.K. Gibson-Graham (2006), examino el papel que jugó el regalo en las negociaciones COPs. Concluyo que pensar a través del afecto ofrece nuevos caminos de conceptualizar las posibilidades emergentes de políticas y prácticas ambientales.

Palabras clave: Conocimiento indígena, contaminantes orgánicos persistentes, Convención de Stockholm, políticas ambientales, el regalo, compartir comida, Gibson-Graham.

\section{Introduction}

In June of 1998, the Inter-Government Negotiating Committee Toward a Global Convention on Persistent Organic Pollutants (POPs) met for the first time in Montreal. On the first day of the meeting, Sheila Watt-Cloutier, an Inuk ${ }^{2}$ woman from northern Quebec who was President of the Inuit Circumpolar Council of Canada, described the importance of country food, or food from the land, for Inuit and other Canadian northern aboriginal peoples, stating:

To sustain ourselves during the last century of rapid change, we have treasured more than ever our land and the food that comes from our land. The process of hunting and fishing followed by the sharing of food, the communal partaking of one animal, is the time honored ritual which links us to our ancestors and each other. The power of this connection holds us together as a people, gives us the spiritual strength and physical energy to survive the challenges we face, and cannot for one second be underestimated.

So imagine for a moment if you will the emotions we now feel-shock, panic, rage, grief, despair-as we discover that the food which for generations has nourished us and keeps us whole physically and spiritually is now poisoning us. You go to the supermarket for food; we go out on the land to hunt, fish, trap and gather. The environment is our supermarket (WattCloutier 1998).

Watt-Cloutier's intervention was intended to humanize the issue of persistent organic pollutants (POPs), chemicals that were carried into the Arctic environment through global air currents, by sharing an example of their impact on Inuit relations with one another and the environment. Her words carried a sense of urgency, compelled by the strong emotions that she named: shock, panic, rage, grief, despair. In this way, Watt-Cloutier invited those assembled in Montreal to feel the impacts of POPs through a sense of human empathy.

Watt-Cloutier drew a parallel between Inuit subsistence hunting and the supermarket, each a source of food and nourishment in their own right. Her statement, however, offered many more contrasts than similarities between the market-based transactions of the supermarket and the socially embedded economy of Inuit hunting. The latter exemplifies what feminist geographers J.K. Gibson-Graham have termed "diverse" or "community" economies (2006[1996]), economic practices with deep social and ecological ties to place. ${ }^{3}$ Watt-Cloutier thus invited the POPs negotiators to think differently about the relationships between production, pollution, and human and environmental well-being by evoking emotion and the affective ties that connect Inuit to one another, to the land, and to animals. Her hope was that by illuminating connections and

\footnotetext{
${ }^{2}$ Singular of Inuit.

${ }^{3}$ Julie Graham and Katherine Gibson publish under the single name J.K. Gibson-Graham.
} 
inter-relationship, she might contribute to an ethic that would support strong action banning the production of polluting chemicals.

In "An economic ethics for the Anthropocene," J.K. Gibson-Graham and Gerda Roelvink (2009) consider the kind of human response required to meet the challenge of global environmental crisis. It is not enough, they suggest, to place our collective faith in technological fixes while continuing to exploit natural resources for economic gain. Rather, an "ethics for the Anthropocene" requires rethinking economic practices through an ethic of relationship with a larger human community and with the non-human world. This, in turn, involves cultivating an embodied reflexivity that, as they phrase it, "...is about human beings being transformed by the world in which we find ourselves" (2009: 322). Following Bruno Latour (2004), they call this process "learning to be affected" (2009: 322).

In this article, I take up and explore Gibson-Graham and Roelvink's "ethics for the Anthropocene" through a discussion of Inuit knowledge and affect in the social economy of food sharing and in global environmental politics. I begin by examining how Inuit knowledge emerges from the distinctly relational practices that tie people to one another, to family, to the land, and to animals. I describe the non-capitalistic economic practices that materialize Inuit knowledge; through these practices, food from the land is shared with family and those in need. I compare the ethics of sharing "country food," as Inuit call food that is hunted, fished, and gathered from the land, with what Gibson-Graham refer to as ethical coordinates of community economies (2006). While all knowledge is mediated by affect, Inuit knowledge offers a clear example of how knowledge is not separate from lived, inter-subjective experience but is constituted by and contributes to it.

In the second part of this article, I describe how Inuit knowledge contributed to an emergent affect of interconnection in the global negotiations leading up to the Stockholm Convention on Persistent Organic Pollutants (POPs). Inuit knowledge was made visible and tangible in the negotiation process through personal narratives that encouraged empathy by way of shared feeling, as well as through the gift of an Inuit carving. Revisiting Marcel Mauss' conception of the gift (1990[1950]), I suggest that affect plays a critical role in the reciprocal ethic of gift giving. Through this example, I demonstrate how thinking through affect offers a dynamic way of understanding the role that Inuit knowledge plays when mobilized in environmental politics. In this case, Inuit knowledge, along with other factors, contributed to a successful outcome in the form of a binding treaty to limit contaminants.

My discussion is informed by anthropological fieldwork conducted in 2009-2010 in Clyde River, a small Inuit hamlet of around 1,000 people on Baffin Island in Canada; Iqaluit, the capital of Nunavut, Canada's newest and largest majority-Inuit territory; and with the Inuit Circumpolar Council (ICC). ICC represents the approximately 155,000 Inuit who live in Alaska, Canada, Greenland, and Chukotka, Russia in international decision-making contexts, including various United Nations conventions and bodies as well as the Arctic Council. My research took place years after the Stockholm Convention was ratified; in addition to examples from fieldwork and interviews, I therefore also draw on published literature and speeches in my discussion of global environmental politics.

\section{Inuit knowledge, food sharing and the social economy}

In the eastern Canadian Arctic, most households rely on a combination of wage labor, welfare, and subsistence practices to meet their daily needs. This diversified approach to making a living has been referred to as both a "mixed economy" and a "social economy" (Harder and Wenzel 2012). A social economy encompasses many institutions and includes both commercial and non-commercial activities and monetary and non-monetary transactions (Restakis 2006; Natcher 2009). For Inuit, sharing country food such as ringed seal, caribou, narwhal, polar bear, and Arctic char represents the most significant form of non-monetary resource exchange.

The Inuit social economy, organized significantly around the central practice of food sharing, is an example of what J.K. Gibson-Graham have termed "community" or "diverse" economies (Gibson-Graham 2006; Burke and Shear 2014). Gibson-Graham question dominant assumptions about capitalism's hegemony and centrality to modern life, pointing out the prevalence of non-capitalistic economic forms. Under the diverse economies framework, certain principles associated with capitalism, such as wage labor, production 
for the market, private ownership of enterprise, and the pursuit of economic growth, become attributes among many other forms of economic and social organization. Subsistence hunting and agriculture, caregiving and household labor, and sharing and gift giving are examples of non-capitalist economic practices that co-exist with capitalist practices (Gibson-Graham 2006).

Community economies structure production, distribution, and consumption in diverse ways, but certain "ethical coordinates" provide a thread that unites them. These include making and sharing a commons, addressing consumption and necessity, and redistributing surplus (Gibson-Graham 2006). ${ }^{4}$ Inuit food sharing touches on each of these ethical coordinates: it is based on a commons, the land (nuna) in which Inuit and animals dwell. Inuit do not view their relationship to the tundra or sea ice as based on ownership, nor do they own the animals they hunt. ${ }^{5}$ Consumption of animals is based on the principle of taking only what is needed and not wasting (Rasing 1994), a strong traditional ethic that largely endures today. Animals are understood to be autonomous, sentient beings that must be treated with respect, including respect for their intelligence (Stairs and Wenzel 1993). Failure to properly respect animals—-for example, by speaking badly about them or wasting parts of animals that have been hunted — can lead to retaliation; an animal that has been disrespected may harm an inconsiderate hunter or avoid him altogether, causing him to come home empty handed (Gombay 2010a; Rasing 1994).

Finally, food sharing is centrally about the redistribution of surplus. George Wenzel has described food sharing as "a strategy for achieving the widest possible distribution of resources in Inuit communities" (1995:46). Food sharing networks are highly structured and follow rules that determine who shares with whom. For example, based on the principle of respect and obedience, younger hunters are often expected to give their entire harvest to the (usually male) head of the family (isumatuq), who then redistributes it among the extended family (Wenzel 1995). ${ }^{6}$ Most food sharing occurs among closely related kin, who may also exchange other goods and services (Harder and Wenzel 2012; Gombay 2010a). Unrelated male hunting partners usually divide the harvest between themselves equally, and hunters with surplus sometimes share with unrelated elders and others in need (Wenzel 1995; Gombay 2010a).

While hunting is primarily a male activity, women support subsistence by gathering seaweed and harvesting berries, making warm clothes, preparing meals, caring for children, butchering meat and preparing skins (Dowsley et al. 2010). Women also play a critical role as wage earners, supplying income to support hunting activities. A broad definition of hunting and food sharing in the social economy therefore incorporates both men's and women's labor (Kafarowski 2009; Bodenhorn 1990).

Country foods not only provide physical nourishment, they are also important culturally, psychologically, and emotionally for many Inuit (Natcher 2009; Gombay 2010a). As anthropologist Jean Briggs has described, country food is a powerful symbol of Inuit identity, and sharing food represents an ethic of care for others. In pre-settlement days, "the giving and receiving of food was a sign that one loved and was loved in return by one's family, and outside the closest circle, the offering of food represented affection and care for one's fellows, one of the most important of Inuit values" (Briggs 1997: 229).

Today, Inuit continue to experience health and well-being in relation to family, sharing food, and spending time on the land (Krall et al. 2011). These associations are common among many aboriginal and First Nations groups in Canada. Naomi Adelson, for example, has described how Cree notions of miyupimaatisiium, or "being alive well," encompass warmth, Cree food, and strength, which are all intimately connected to life on the land and hunting traditions (Adelson 2000). Similarly, David Natcher suggests that aboriginal cultures in Canada are "rooted in the landscape, and cultural values are perpetuated through continued land use activities" (2009: 87).

\footnotetext{
${ }^{4}$ Gibson-Graham define the concept of the commons broadly; a commons can include, just to offer some examples: shared land and physical spaces such as a community center, environmental goods such as water, biodiversity, and the atmosphere, and technologies and informational goods such as the Internet or a shared database.

${ }^{5}$ As a result of land claims processes, Inuit do have collective rights to land that are enshrined in a Western legal paradigm of ownership. These include rights to use and manage the land and to pursue non-renewable resource development.

${ }^{6}$ For detailed descriptions of the structure of food sharing networks see Damas (1972) and Wenzel (1995).
} 
In Clyde River, a young man named Eli told me about catching his first and only seal with his uncle at age $16 .^{7}$ Eli wore the low-riding jeans and hoodie typical of teenage boys. He was working towards his GED and hoped to be able to get a job in construction. His own father did not hunt and Eli rarely had the chance to spend time on the land. He told me that he had felt excited and special when his uncle took him hunting on the sea ice in March several years before. His uncle instructed him on how to pay attention at the seal's breathing hole near the floe edge, the place where land-fast ice meets open water, until a seal appeared under the ice. Eli waited, heart racing, and he told me that when he shot the seal and retrieved it, "I felt so happy!" I asked him why it was so important to get this seal, and he said, "Because it's Inuit culture, or Inuit favorite food." He brought the seal to his grandmother's house and, following traditional practice, did not eat any himself but divided it among close family members to enjoy.

Eli's story demonstrates how Inuit knowledge — knowledge of the land, animals, hunting, and sharing food-is part of a web of action and relationship. His rush of happiness at the floe edge where he hunted his first seal had to do with many things: with his uncle's attention and mentorship, with being out on the land and mastering a skill that is central to male Inuit identity, and with the knowledge that he could now provide food to his extended family. From this perspective, Inuit knowledge cannot be divorced from economic life, kinship, the land, animals, or emotional experience; it is fed by and feeds into each of these.

\section{Learning to be affected}

This way of understanding Inuit knowledge has parallels in Hugh Raffles' concept of "intimate knowledge" (2002). Raffles describes a boat trip on the Amazon River in which the vessel that was ferrying him and his fellow passengers caught on a sandbar and nearly overturned. Reflecting on the contingencies of luck and skill through which the captain managed to free the boat, Raffles writes that intimate knowledge:

...recalls the intimate, lived experience of everyday life: the textured intimacies among men and women, and those between people and these mercurial fluvial landscapes. This incident reminds me how on these rivers people enter into relationships among themselves and with nature through embodied practice; how it is through these relationships that they come to know nature and each other; and how the relationships, the knowledge, and the practice are always mediated not only by power and discourse, but by affect. And it also brings to mind how affect, though inconstant, is also ubiquitous, the perpetual mediator of rationality (Raffles 2002: 326).

Knowledge, Raffles suggests, is about intimacy; it reflects all the different kinds of relations that a person develops with people, landscapes, and objects. Raffles points in particular to the role of affect as a mediator of thought and reason. This conception places knowledge, traditionally theorized in Western epistemology as based in a rational, thinking mind separated from the sensuous domain of the body, back in the messy, emotional, physical and material plane of lived experience. Similarly, Analiese Richard and Daromir Rudnyckyj suggest that affect and reason "are not necessarily confined to separate realms of social action, and in some cases are in fact mutually constitutive" (2009: 62). From this perspective, affect not only mediates reason, but reason can also contribute to affect.

In his analysis of what has been described as the "affective turn" in social and cultural analysis, William Mazzarella suggests that "thinking affect points us toward a terrain that is without being presocial" (2009: 291). He explains that affect is "both embodied and impersonal" (p.292), pre-subjective in the sense that it references a register of social life that exists beyond symbolic mediation and discursive elaboration, the latter of which lie in the domain of culture. Others have also noted the inter-subjective, in-between, and experiential qualities of affect, distinguishing it from the largely individual and subjective character of emotion (Navaro-Yashin 2009; Roelvink 2010; Seigworth and Gregg 2010). As Gregory J. Seigworth and Melissa Gregg claim, affect is: "...the name we give to those forces-visceral forces beneath, alongside, or

\footnotetext{
${ }^{7}$ I use a pseudonym here based on Eli's preference. In Clyde River, killing an animal is often colloquially described as "catching" it.
} 
generally other than conscious knowing, vital forces insisting beyond emotion - that can serve to drive us toward movement... [or can] leave us overwhelmed by the world's apparent intractability" (2010: 1).

While Richard and Ruduyckyj (2009) see affect as a component of both subjectivity and collective action, Yael Navaro-Yashin suggests that affect is "post-subjective" (2009) because it is influenced not only by humans, but also by space, the environment, and material objects. Affect can therefore be described as the "merging of the forces, energies, and affective potentialities of human beings, with their natural, built, and material environment" (Navaro-Yashin 2012: 27). Affect is connected to agency in that it saturates or permeates human/human and human/non-human relations, allowing particular possibilities for action to emerge and take shape. Navaro-Yashin suggests that affect is "a charge that has a part to play in the sociality of the human beings who inhabit a space" (2012: 20). For Richard and Rudnyckyj, affect is analytically useful in examining social and economic transformation because, as both a noun and a transitive verb, affect "simultaneously makes both its subject and its object" (2009: 59). They continue: "It is this transitive and reflexive capacity of affect-actions that affect others and oneself-that makes it particularly useful for documenting how subjects are mutually constituted" (2009: 59).

Gibson-Graham and Roelvink (2009) take up the question of affect in their discussion of an ethics for the Anthropocene. Developing such an ethic, they suggest, first entails learning to be affected, a cultivation of self in relation to others and the physical world. It involves learning through and inhabiting the body and bodily senses and therefore also creatively engaging with and helping to constitute the world. Their discussion of learning to be affected has some parallels in anthropological attempts, rooted in phenomenology, to define the character of Indigenous knowledge. Unlike the splitting of mind and body that is characteristic of western thought traditions, Indigenous knowledge is embodied, tacit, and emergent. Under this understanding of knowledge, mind is not limited to the parameters of the human body, but rather extends outward through sensory perception into the environment, itself (Bateson 1973; Ingold 2000; Ingold 2008).

Gibson-Graham and Roelvink suggest that they are "...interested in thinking about learning to be affected as an ethical practice, one that involves developing an awareness of, and in the process being transformed by, co-existence" (2009: 325). Their statement suggests that while affect itself may be preconscious and pre-subjective, an awareness of affect can be consciously cultivated.

Reading this, I recalled a conversation with Ilkoo Angutikjuaq, an elder and expert hunter I spoke with in Clyde River. We were discussing weather prediction, a traditional skill that has declined in recent years, partly because the weather is acting strangely due to climate change and is harder to predict using the old methods (Gearheard et al. 2010; Krupnik and Jolly 2002). Angutikjuaq told me that when he was a boy, he lived with his older brother who was like a father to him. Every morning on waking, his brother would tell him to go outside.

I used to feel like complaining because I felt like they [older generations] were pushing me around, telling me to go outside. But they did that to all the young people then. As soon as they woke up, they made them go outside... [In this way] they taught us lessons. They didn't say: I want you to go out because I want you to observe the weather. They didn't come right out and tell us that. But they would say: you need to go outside every day. They taught us to become moral that way. (Interview with the author, July 16, 2009). ${ }^{8}$

In the changeable Arctic, knowing how to observe, predict, and respond to subtle environmental indicators is important for survival. Angutikjuaq's brother was teaching him a particular kind of attentiveness and awareness of the environment as a whole, a continuous searching for clues in such varied phenomena as the wind direction, the way the snow drifts are pointing, the way that animals are behaving, and the way that clouds are forming in the sky. As Angutikjuaq suggested, though, his brother was also teaching him "to become moral." Becoming moral in this sense requires a social awareness that encompasses both the human and non-human. It involves having respect for elders and doing what they say even if you do not fully

\footnotetext{
${ }^{8}$ I would like to acknowledge Geela Tigullaraq's skillful role as interpreter of this interview.
} 
understand the reasons why it is important. Additionally and significantly, becoming moral is also about cultivating a respect for and understanding of the wider environment.

Like Angutikjuaq, others have described the ways that Inuit knowledge and land skills contribute to a sense of ethical comportment. Nicole Gombay suggests that sharing country food is part of "a geography of morality that inheres in place" (Gombay 2010b: 239, emphasis in original). Learning the skills of the hunt, as Eli had begun to do when his uncle took him to the floe edge, is understood to be integral to the development of wisdom, intelligence, patience, and humbleness, among other qualities (Searles 2010; Takano 2005). Inuk environmental and human rights activist Sheila Watt-Cloutier, whose discussion of persistent organic pollutants opened this article, offered this analysis:

Hunting is, in reality, a powerful process where we prepare our young for the challenges and opportunities not only for survival on the land and ice but for life itself. The character skills learned on the hunt of patience, boldness, tenacity, focus, courage, sound judgment and wisdom are very transferable to the modern world that has come so quickly to the Arctic (WattCloutier 2007).

Based on Watt-Cloutier's description, the transmission of hunting knowledge, which includes both men's and women's labor and attention, involves not only practical skills, but also what she calls "character skills," qualities that guide the relations an individual develops within his or her surroundings. Character skills are transmitted in part through embodied, practical knowledge of the land and animals but are also general, relevant to what Watt-Cloutier refers to as "life itself" and therefore transferable to other contexts and situations, including global environmental negotiations.

These examples of ethical and moral character development mirror the explicitly ethical register of Gibson-Graham's conception of "learning to be affected." Ethical development, from this perspective, is informed by attuning oneself to the inter-subjective, embodied domain of being, the domain of affect, which Mazzarella suggests is akin to "a social aesthetics, if we understand by aesthetics the ancient Greek sense of aesthesis or sense experience" (2009: 293). Affect can best be experienced through the senses in all their fullness, a kind of feeling that structures and informs the development of self, situated in a wider social and environmental context (Richard and Rudnyckyj 2009).

In the Inuit context, knowledge and ethics are linked through affect. Knowledge is explicitly garnered through attunement to the social and physical environment; learning to be a hunter requires learning to be attentive to signs in the wind, ice, snow, and weather, while also staying tied to the social body and following moral and ethical guidelines of personal comportment, which includes sharing food. These are examples of what Gibson-Graham described as "learning to be affected."

A theory of affect can also contribute to an understanding of Inuit knowledge as both locally and globally emergent and dynamic. In the next section, I return to the topic of persistent organic pollutants and the political negotiations that eventually resulted in a ban on chemicals that were most harmful to human health. My discussion focuses on the role of Inuit knowledge in the work of the Inuit Circumpolar Council (ICC), an organization formed in 1977 by Inuit from Canada, Alaska, and Greenland to respond to threats to their shared Arctic environment posed by offshore oil and gas development. ${ }^{9}$ Following Sheila WattCloutier's analysis of Inuit knowledge and the example she set during the POPs negotiations, I suggest that thinking with and through affect illuminates the emergent, dynamic role of Inuit knowledge in global political negotiations. It also enables a more fluid, of-the-moment analysis of politics in action.

\section{Inuit knowledge and affect in global environmental politics}

In 2002, Sheila Watt-Cloutier was elected international Chair of the Inuit Circumpolar Council (ICC) and was invited to speak with leaders of the government of the newly formed Nunavut Territory, which was

\footnotetext{
${ }^{9}$ Russian Inuit from Chukotka joined ICC in 1992 after the fall of the Soviet Union. Today, ICC has offices in each of these four countries, and is governed by an Executive Council and a Chair that rotates among the four countries.
} 
established in 1999 as the result of a land claims process. The Government of Nunavut was developing a policy on how Inuit Qaujimajatuqangit (IQ), translated as "the past, present, and future of Inuit knowledge" (Arnakak 2000), would inform government practice, and they asked Watt-Cloutier to speak about IQ in ICC's international engagements. ${ }^{10}$

In her remarks, Watt-Cloutier identified two aspects of Inuit knowledge that shaped how ICC conducted its work internationally. One of these was to draw attention to traditional knowledge, particularly related to the land, as an important resource for policy; the other was to "project the values, philosophy, culture and political goals of Inuit to decision-makers" (Watt-Cloutier 2002: n.p.). She continued: "This is not only to defend Inuit rights and interests but to suggest that the Inuit view and approach to consensus building and healing, the essence of Inuit Qaujimajatuqangit, is relevant to a world driven by self-interest" (Watt-Cloutier 2002). Watt-Cloutier suggested that IQ is "both the medium and the message," both traditional ecological knowledge as well as "the context in which to bring forward or embed" Inuit knowledge and experience in international politics (Watt-Cloutier 2002). In other words, the relational and ethical orientation of Inuit knowledge shaped ICC's work, and helped pave the way for Inuit within international diplomatic spaces.

Watt-Cloutier offered the example of ICC's work on persistent organic pollutants (POPs) to illustrate what she meant by a consensus building and healing approach. From 1998 to 2001, delegates of 152 countries met in a series of formal and informal consultations to negotiate a new treaty on contaminants, including pesticides, industrial chemicals, and by-products. The negotiations followed years of preparatory work prompted by Agenda 21 of the United Nations Conference on Environment and Development, often referred to as the Rio Earth Summit, which outlined the need for more international cooperation on toxic chemicals. They were also precipitated by significant research on pollutants through the Canadian government's Northern Contaminants Program (NCP), initiated in 1991 to study and understand the pathways through which pollutants moved through the northern ecosystem and how this impacted animal and human health.

In the 1980s and early 90s, scientists working in the Arctic had found that chemical pollutants from industrial emissions, carried northward through global air currents, were present in the body fat of living organisms. Concern began to develop when public health researchers examined levels of polychlorinated biphenyls (PCBs) in breast milk samples collected from Inuit mothers in Canada. Researchers had anticipated finding lower levels of contaminants among Inuit, since they lived far from centers of industry. Instead, the studies showed concentrations of PCBs at levels that were five to ten times higher than in the breast milk of women tested in southern regions of Canada (Dewailly and Furgal 2003).

PCBs are chemical compounds that were widely used in a variety of industrial and commercial applications including electrical appliances, insulation, oil-based paints, plastics, and motor oil. Released into the environment through municipal and industrial incineration and household waste burning, PCBs travel through air currents to the Arctic, fall with snow onto the tundra and into the ocean, are taken up by lichen, plants, and algae, and are consumed by many of the animals that Inuit enjoy eating and depend on for nutrition (Blais 2005; Commoner et al. 2003). Because the compounds were slow to break down, they accumulate in greater quantities in animals higher up the food chain, a process referred to as biomagnification. This places humans who consumed marine mammals at particular risk of accumulating toxins in their own body fat.

Studies have linked PCBs to a number of health impacts in animals, including humans, with the greatest impacts linked to in utero exposure. These include a possible correlation between prenatal exposure and acute infections in infancy including bronchitis and pneumonia (Dallaire et al. 2004; Dallaire et al. 2006), and impaired learning and intellectual functioning (DeWailly and Furgal 2003). Studies of exposure in adults found negative impacts on immune system function, changes in genetic expression, and possible links to nonHodgkin lymphoma (Kramer et al. 2012; Rusiecki et al. 2008).

ICC-Canada, under the presidency of Sheila Watt-Cloutier, was one of five Canadian Indigenous peoples' organizations to join federal agencies and territorial governments in directing and managing the

\footnotetext{
${ }^{10}$ For more on IQ and its relationship to government and bureaucracy see Ailsa Henderson (2007), Frédéric Laugrand and Jarich Oosten (2009) and Graham White (2006).
} 
Northern Contaminants program (Fenge 2003). When the international community took up the issue, ICC drew on this experience to help form a coalition called Canadian Arctic Indigenous Peoples Against POPs (CAIPAP). Watt-Cloutier was the most consistent representative for CAIPAP, attending all of the POPs negotiations alongside more than 600 observers from industry, inter-governmental, and non-governmental organizations (Downie 2003). ${ }^{11}$ In this context, Watt-Cloutier's particular interest was in humanizing the issue of POPs by focusing on the harm done to the subsistence practices and cultural and environmental relationships of Inuit and other Arctic Indigenous communities.

As described at the beginning of this article, when Watt-Cloutier had the opportunity to address the people gathered at the first Inter-Governmental Negotiating Committee meeting on POPs, she did so in a distinctly affective register. Watt-Cloutier invited her audience to understand contaminants from the perspective of Inuit, who have experienced significant and ongoing change over the past century, much of which was directly or indirectly introduced by qallunaat (non-Inuit/Euro-American) society. For Inuit, contaminants represent yet another challenge to the persistence of local forms of sociality that are perhaps best embodied in the hunting and sharing of country food. She asked her audience of negotiators and observers to imagine "the emotions we now feel—shock, panic, rage, grief, despair—as we discover that the food which for generations has nourished us and keeps us whole physically and spiritually, is now poisoning us" (Watt-Cloutier 1998: n.p.).

The use of a language of emotion and the invitation to feel the impact of contaminants in an affective register reflected Watt-Cloutier's explicit interest in humanizing the POPs negotiations. It also reflected a larger shift in political and institutional life towards what William Mazzarella has termed "affect management" (2009). As Mazzarella notes, our public cultures have become increasingly and "unabashedly" affective; we have become accustomed to "being solicited in an unprecedentedly affective, intimate register" (2009: 291). His conception of affect management reflects the institutionalization of affect as a part of daily life, something that has become essential to political and institutional endurance.

Reflecting this affective turn in politics, at the POPs negotiations, well-funded chemical company lobbies also presented emotional testimonies, arguing that a ban on chemicals like DDT, which along with commercial applications was also used as an insecticide in malaria control efforts, would cause undue suffering for people in sub-Saharan Africa. Like Watt-Cloutier, they hoped that negotiators would connect on an emotional level with stories of hardship and suffering. By emphasizing the humanitarian uses of these chemicals, corporate spokespersons tried to gloss over the question of profit and the economic losses they would face if a ban on the chemicals they manufactured was enacted. Their strategy, while affective, was also divisive; they sought to emphasize the suffering of those with malaria over the suffering of those affected by contaminants.

In contrast, ICC and CAIPAP supported banning POPs, including DDT, based on a sense of collective harm that bridged geographic boundaries. CAIPAP's perspective was that the economic arrangements that underwrote the sale of chemicals to prevent malaria benefitted large companies and their executives and stockholders, none of whom faced significant risks from either malaria or from food contaminated by toxic chemicals. As Stephanie Meakin, ICC's Science Advisor, explained, "We recognized that it was a North/South divide, that chemicals were being manufactured in the North, and all the profits were taken by the North, and they were being used in the South, and then coming back North."

While Watt-Cloutier had been granted time to offer testimony during the first POPs negotiating session in Montreal, this opportunity is never guaranteed to observer groups within UN negotiations. During the months leading up to the second round of negotiations, held in Nairobi in 1999, ICC was concerned about whether they would again have the chance to share an Arctic Indigenous perspective directly with negotiators;

\footnotetext{
${ }^{11}$ The other members of CAIPAP included Inuit Tapiriit Kanatami, the national Inuit organization of Canada, the Dene Nation, Métis Nation-NWT, and the Council of Yukon First Nations. CAIPAP collaborated with other Arctic Indigenous peoples, including the Saami Council and the Russian Association of Indigenous Peoples of the North (RAIPON). Another Indigenous peoples' organization that was closely involved in the POPs negotiations was the US-based Indigenous Environmental Network, led by Tom Goldtooth.
} 
in order to do so, Watt-Cloutier needed to gain the attention of those who had authority to grant her time to speak on the floor.

As Stephanie Meakin explained to me: "So then we decided: give them a gift. They can't ignore us if we give them a gift." En route to Nairobi, Meakin purchased a carving of an Inuit mother and child at the airport gift shop in Ottawa, lugging it in her hand baggage through airport transfers, out into the muggy heat outside the Nairobi terminal, and back into the air conditioned cool of the meeting facilities. There, WattCloutier presented the carving to the lead UN negotiator, Klaus Töpfer, Executive Director of the United Nations Environment Program (UNEP), at a reception UNEP was hosting. Töpfer accepted the gift and then presented it in turn to John Buccini, who was chairing the negotiations. In doing so, he gave an impromptu speech in which he suggested that Indigenous peoples were the "conscience" of the negotiations (Fenge 2003). As Buccini described this re-gifting, Töpfer offered him the statue: "...with the request that it be displayed during the negotiations as a constant reminder to the delegates of the significance and importance of our task" (Buccini 2003). The statue (Figure 1) therefore became a representation of the health and environmental concerns of Inuit and other Arctic Indigenous peoples. It sat in front of Buccini for the rest of the week, making further appearances at press conferences and at subsequent negotiations in Geneva, Bonn, Johannesburg, and Stockholm.

Figure 1: The Inuit mother and child carving. Source: $\underline{\text { iisd.ca }}$

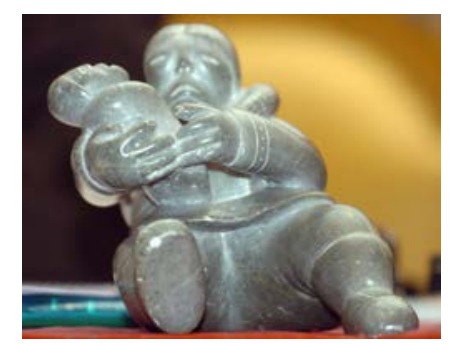

In his classic essay, The Gift (1990[1950]), Marcel Mauss considered the reciprocal nature of gift giving. A central theme of his discussion focused on the question of why gifts must be repaid. Mauss suggested that, unlike in a commodity economy, in a gift economy, objects are never fully alienated from the giver, they are in some sense "loaned" rather than given. This means that objects given as gifts retain part of the identity of the giver, which in turn creates an obligation on the part of the receiver to reciprocate. Gifts therefore create and solidify a bond of relationship based on reciprocity. In giving and receiving, a relationship is established that over a period of time becomes a strong social tie.

Thinking through affect offers a different way of understanding the social work effected by this gift. Gifts can be seen as a materialization of social relations that evoke a particular feeling of connection, a sense of being part of the same field of lived experience. The material nature of the gift is significant to the way it affects the receiver; its physicality, its utility, and its aesthetics are part of what makes the gift productive of feeling. At the same time, the gift is affective not just because of its immediate, physical properties, or because of its imagined future utility, but also because it both references and partakes in a web of human and environmental sociality. Gifts refer to relationships; their value is derived in large part because of this referential action. At the same time, the materiality of gifts is important because it helps build connection beyond language in the here-and-now of the space in which they are offered and received. Recalling Yael Navaro-Yashin's suggestion that affect is "a charge that has a part to play in the sociality of the human beings who inhabit a space" (2012: 20), gift giving contributes to this charge, this sense of emergent possibility in a space of human engagement. Within the domain of affect, new social ties can be formed and old ones solidified.

What role did the Inuit carving play in mediating the affect of empathy that emerged from the action of gift giving? Navaro-Yashin (2009) took up a similar question in her consideration of the materiality of affect in Turkish Cyprus. Her work focused on the after-effects of the partition of Cyprus in 1974, when Greek Cypriots living in the north and Turkish Cypriots living in the south were forced to leave behind "properties, homes, animals, and personal belongings" (2009: 2). Afterward, each group inhabited the properties and took 
up the belongings of the other. In such an environment, "relations with the other community persist in the imagination through interactions and dealings with their abandoned properties, spaces and belongings" (2009: 2). For Turkish Cypriots, a predominant feeling that emerged from these interactions was that of melancholy. Navaro-Yashin wondered: "Is the affect of melancholy experienced in relation to looted objects and properties a projection of their users' subjectivities onto the objects or an energy discharged out of these objects themselves?" (2009: 8).

Her question brings to mind Mauss' notion that gifts continue to hold something of the original owner's essence, which is partly what compels their new owners to return the favor. Navaro-Yashin concludes that melancholy is mediated both through the subjective, emotional experiences of individuals, as well as through objects and non-human environments. This of course is not a magical property of the objects, but rather emerges from the way that human collectives relate to objects. She states: "This object... reminds the persons who use or inhabit it that it, itself, is a loss to the persons who were its original owners" (2009: 16).

In a similar sense, the statue of the Inuit mother and child carried a particular affect that permeated the spaces in which the Stockholm Convention was negotiated. ICC's gift can be understood to have created an expectation of reciprocity by uniting the giver and receiver in an affective register, a feeling of intimate possibility that encompassed the experience of life in the Arctic along with the shared immediate experience of the UN gathering.

After receiving the gift and being affected by it, Buccini did indeed reciprocate, granting ICC three minutes to present an intervention at the beginning of the meeting. Watt-Cloutier used this time to introduce her moral argument of human interconnection and global common cause, stating:

Many Inuit mothers, far from areas where POPs are made and used, hesitate to breastfeed their babies. This is a wake-up call to the world. Here in Nairobi, I have met women from many African countries who worry greatly about the effects of pesticides on their children. We have a common cause. A coalition of citizens, particularly women, from all regions of the globe is forming to demand that you, the governments of the world, take concrete and effective action to rid us of the POPs threat to our children (Watt-Cloutier 1999).

As Navaro-Yashin cautions in her analysis of the materiality of affect, "Objects are not involved in relations with human beings in a linguistically or symbolically neutral arena. Objects are, rather, qualified through language" (2009: 10). In this case, Töpfer's exhortation that the carving should serve as a reminder to those assembled of the "importance of their work" helped create a context in which it was granted a particular kind of attention by those assembled. Through this discursive act, the statue effectively became the embodiment of Watt-Cloutier's moral argument. Through its continued physical presence at the negotiating table, the carving reminded parties about Watt-Cloutier's message of the human risks of POPs long after her three minutes of speaking time were up.

Watt-Cloutier's speech also helped expand the sense of feeling the gift introduced, translating and making its ethic of reciprocity more legible through human discourse. In her own words, the speech was "designed to be selfless and healing, reflecting an Inuit Qaujimajatuqnagit and Inuit wisdom approach to the world" (Watt-Cloutier 2002). This understanding of Inuit knowledge calls to mind Gibson-Graham and Roelvink's interest in what they call the "open stance," which reflects "a posture of openness, of welcoming, of invitation" (Plumwood 2002: 175-76, in Gibson-Graham and Roelvink 2009: 324). In such a stance, the body and mind are receptive and open to new ideas, do not prejudge or limit what is possible, but rather are ready to partner, learn from, and be transformed by both human and non-human others (2009: 324). Adopting an open stance is a necessary part of learning to be affected.

The gift of the statue represented an invitation to participate in an empathic rather than an adversarial approach to diplomacy based on an open stance, a willingness to be affected. Klaus Töpfer and John Buccini's acceptance of the statue and their designation of it as the "conscience" of the meeting suggests that these affective dimensions of Inuit knowledge can call forth an emotional resonance in others who have no personal experience of the Arctic environment. By appealing to points of commonality rather than advocating from a 
perspective of self-interest, Watt-Cloutier engaged in what she called a "politics of influence" rather than a "politics of protest" (Watt-Cloutier 2002). The speech and the material, aesthetic, and performative gift of the statue both contributed to ICC's effective management of affect, which might be considered part of the repertoire of Inuit knowledge.

\section{Discussion}

In 2001, the Stockholm Convention on Persistent Organic Pollutants was adopted. An initial 121 state parties ratified it; as of 2013, it has 179 Parties and 152 Signatories. ${ }^{12}$ Convention Parties agreed to ban nine of the original 12 "dirty dozen" pollutants and to limit DDT to malaria control only. Parties also agreed to continue to review new compounds for consideration to add to the Convention; in 2009, nine new POPs were added.

Speaking in Stockholm on the eve of the convention's adoption, Watt-Cloutier reflected on the role that Inuit had played in the negotiations. She quoted Admiral Peary, the Arctic explorer credited with leading the first expedition to reach the geographic North Pole in 1909, who said:

I have often been asked: Of what use are Eskimos to the world? They are too far removed to be of any value for commercial enterprises; and furthermore, they lack ambition. They have no literature; nor, properly speaking, any art. They value life only as does a fox, or a bear, purely by instinct. But let us not forget that these people, trustworthy and hardy, will yet prove their value to mankind. With their help, the world shall discover the pole (Harper 1986: 7, in WattCloutier 2001).

Peary's interest in Inuit was largely instrumental, and his writing reflected the colonial attitudes of his time. Peary lived with Inuit in northern Greenland for several years and learned invaluable skills of survival from them that enabled his successful expedition, including dog teaming, igloo building, and hunting local game. For him, the "value" of Inuit was the role they and their knowledge of the environment played in enabling the "discovery" of the North Pole by Europeans. Nevertheless, his statement hints at a global role for Inuit and their knowledge, and it was this role that Watt-Cloutier invoked when she reframed Peary's quote in her own remarks on the POPs process. She concluded: "I would suggest to you that Inuit and Indigenous Peoples, by engaging in the politics of influence rather than the politics of protest, have not only helped the world find the pole, but... have helped you discover the globe's conscience."

As I describe in this article, the affective dimensions of Inuit knowledge bridge life on the tundra and participation in global environmental politics. Because Inuit knowledge about the land and animals is substantiated in country food that hunters bring home to share with their families, it cannot be separated from bodily practice and skill, or from the social and ethical nexus of life within the family. It therefore reflects what Hugh Raffles termed "intimate knowledge" (2002), the affective register through which all forms of social action take place, and in which knowledge is put to work in the world.

Through land claims and other forms of political and legal recognition, Inuit have become increasingly involved in governance across different scales of practice. In each governance context, from the Government of Nunavut to the Inuit Circumpolar Council, Inuit are actively engaged in thinking about the meaning of Inuit knowledge, sometimes called Inuit Qaujimajatuqangit (IQ), and what it offers to political decisionmaking. Sheila Watt-Cloutier equated IQ with particular habits of mind, developed through bodily practice and relationship to place, that she suggested can be drawn on in non-local decision-making contexts. IQ, then, is not so much about knowledge per se than about the sum total of ethical and social relations from which knowledge emerges.

\footnotetext{
12 Parties are states that have ratified a treaty and are legally bound by it; signatories indicate their support for a treaty without the same level of legal commitment. The United States has signed the Stockholm Convention but has not ratified it.
} 
Increasingly, Inuit knowledge contributes to the unfolding of social relations and new political possibilities in global politics. At the POPs negotiations, ICC's gift of an Inuit carving contributed to an emergent ethic of reciprocity and relationship that prioritized environmental health over corporate profit. The gift was part of an ensemble of actions by ICC that also included sharing stories about the Inuit social economy and hunting practices, sharing country food with delegates, and performing drum dances (WattCloutier 2002). Through these narratives and embodied actions, meeting delegates and observers gained a sense of the environmental, social, ethical, and economic relations that are encompassed in Inuit knowledge.

It is worth pointing out that not all gifts would have been equally acceptable to the individuals leading the POPs negotiation process. For example, if one of the chemical companies offered a gift to the Chair, it's hard to imagine that he would place it next to him on the table to remind delegates of the significance of their work. Rather, Töpher and Buccini's acceptance of the gift was based on their essential agreement with ICC that a ban on the "dirty dozen" - the 12 most polluting and hazardous chemicals, was the desired outcome of the negotiations. It is therefore difficult to pinpoint exactly what difference the statue in particular, or Inuit knowledge more broadly, made in these negotiations. As Gerda Roelvink has stated, "Affect is not a force that can be directly observed or documented" (Roelvink 2010: 112); it is difficult to capture or measure the role of affect in any setting.

What I risk in discussing the affective properties of Inuit knowledge is that I will be misunderstood as equating affect with the traditional, and therefore missing entirely the analytic value of affect in theorizing the contemporary. I therefore want to clearly state my understanding that Inuit knowledge is of-the-contemporary just as much as any other knowledge form, and that what affect offers is the chance to begin in a place beyond language, to start to conceptualize how knowledge feels and what kind of work it does before it becomes labeled as such. I also want to avoid conveying the idea that affect is somehow a property of Inuit knowledge, or of non-capitalism, both of which represent social forms that are easily romanticized. This is clearly not the case. Affect, as many of the theorists that I have cited in this section have emphasized, is pre-cultural, and this means that while it is a property of the social, it is not a limited to any particular social or cultural context. It is, as Raffles claimed, ubiquitous but also specific, experienced in the "intimate, lived experience of everyday life: the textured intimacies among men and women, and those between people and ... landscapes" (Raffles 2002: 326). In other words, a similar kind of analysis could be done in a different ethnographic context; here, I have used the ethnographic materials available to me to illustrate the relationship between affect and knowledge in the Inuit social economy and food sharing practices, of learning to be affected as letting the wind and weather shape ethical and moral development.

It is also important to note that not only Inuit knowledge, but also other knowledge traditionsincluding Western science-contribute to affect in various ways. Many Western-trained scientists have suggested, for example, that science evokes a feeling, not of certainty, but rather of appreciation for mystery and a sense of wonder and awe about the world. As biologist E.O. Wilson described this sense of mystery in his own work: "One's sense of wonder grows exponentially: the greater the knowledge, the deeper the mystery and the more we seek knowledge to create new mystery" (Wilson 1984).

In other contexts, scientific representations of risk may leave audiences feeling overwhelmed or abstracted. For example, the charts and graphs that scientists use to convey information about climate models might be said to create a distancing and emotionally muting effect. After viewing temperature graphs projected for the audience assembled at the 2007 launch of the IPCC's Fourth Assessment Report, a reporter for the Guardian newspaper commented with dry humor: "This is how the world ends: not with a bang, nor with a whimper, but with a PowerPoint presentation" (cited in Hamblyn 2009: 234). In the context of affect, his statement brings to mind Seigworth and Gregg's description of affect as the "visceral forces... that can serve to drive us toward movement... [or] leave us overwhelmed by the world's apparent intractability" (2010). 


\section{Conclusion}

In the POPs negotiations, scientific studies of human health and environmental risk were critical in prompting national governments to enter into negotiations in the first place (Shearer and Han 2003), and Inuit as well as environmental activists drew on science to shape their interventions and arguments (Fenge 2003). The politics of affect in this setting was therefore complex, not attributable to any single effort or intervention. The statue as a symbol for Inuit knowledge and Inuit knowledge as a model of relational ethics-these clearly made a contribution to the negotiations. Yet it is not my intention to suggest that ICC's engagement can be said to have offered a singularly significant contribution to the Stockholm Convention's ban of the world's most polluting chemicals.

Rather, what I suggest is that much more attention needs to be paid to affect as a tool of politics. Affect mediates between individual and collective, past and present, and human and non-human in powerful ways. It can therefore help forge a connection to environments and agents far from the cloistered rooms where political decisions are often made. What I offer here is a case study that I hope will prompt others to examine affect in the context of environmental governance and political engagement in new and creative ways. Thinking about Inuit knowledge as affect helped me understand more clearly and explicitly the connection between the local practices of sharing country food and the global diplomatic work of Sheila Watt-Cloutier and the ICC. Perhaps more attention to affect in environmental politics will lead others to see connections and build bridges between experiences at different scales and to identify ways that non-capitalist logics and practices can and do contribute to an ethics for the Anthropocene.

\section{References}

Adelson, N. 2000. 'Being alive well': health and the politics of Cree well-being. Toronto: University of Toronto Press.

Arnakak, J. 2000. Commentary: what is Inuit Qaujimajatugangit? Using Inuit family and kinship relationships to apply Inuit Qaujimajatuqangit. Nunatsiaq News Online. [Accessed 1/25/13] http://www.nunatsiaqonline.ca/archives/nunavut000831/nvt20825_17.html

Bateson, G. 2000[1972]. Steps to an ecology of mind: collected essays in anthropology, psychiatry, evolution and epistemology. Chicago: University of Chicago Press.

Beck, U. 1992. Risk society: toward a new modernity. London: Sage Publications.

Blais, J.M. 2005. Biogeochemistry of persistent bioaccumulative toxicants: processes affecting the transport of contaminants to remote areas. Canadian Journal of Fisheries and Aquatic Sciences 62: 236-243.

Bodenhorn, B. 1990. 'I'm not the great hunter, my wife is': Inupiat and anthropological models of gender. Études/Inuit/Studies 14: 55-74.

Briggs, J. L. 1997. From trait to emblem and back: living and representing culture in everyday Inuit life. Arctic Anthropology 34: 227-235.

Buccini, J.A. 2003. The long and winding road to Stockholm: the view from the chair. In D. L. Downie and T. Fenge (eds.) Northern lights against POPs: combatting toxic threats in the Arctic. Montreal and Kingston: McGill-Queens Press. Pp. 224-255.

Burke B.J. and B.W. Shear. 2014. Introduction: engaged scholarship for non-capitalist political ecologies. Journal of Political Ecology 21: 127-144.

Commoner, B., P.W. Bartlett, K. Couchot, and H. Eisl. 2003. The deposition of airborne dioxin emitted by North American sources on ecologically vulnerable receptors in Nunavut. In D.L. Downie and T. Fenge (eds.) Northern lights against POPs: combatting toxic threats in the Arctic. Montreal and Kingston: McGill-Queens Press. Pp. 87-109.

Dallaire, F., E. Dewailly, C. Vézina, C. Vézina, G. Muckle, J-P Weber, S. Bruneau, and P. Ayotte. 2006. Effect of prenatal exposure to polychlorinated biphenyls on incidence of acute respiratory infections in preschool Inuit children. Environmental Health Perspectives 114: 1301-1305. 
Dallaire, F., E. Dewailly, G. Muckle, C. Vézina, S.W. Jacobson, J.L. Jacobson, and P. Ayotte. 2004. Acute infections and environmental exposure to organochlorines in Inuit infants from Nunavik. Environmental Health Perspectives 112: 1359-1364.

Damas, D. 1972. Central Eskimo systems of food sharing. Ethnology 11(3): 220-240.

Dewailly, E., and C. Furgal. 2003. POPs, the environment, and public health. In D. L. Downie and T. Fenge (eds.) Northern lights against POPs: combatting toxic threats in the Arctic. Montreal and Kingston: McGill-Queens Press. Pp. 3-21.

Downie, D. L. Global POPs policy: The 2001 Stockholm Convention on Persistent Organic Pollutants. In D. L. Downie and T. Fenge (eds.) Northern lights against POPs: combatting toxic threats in the Arctic. Montreal and Kingston: McGill-Queens Press. Pp. 133-159.

Dowsley, M., S. Gearheard, N. Johnson and J. Inksetter. 2010. Research note: should we turn the tent? Inuit women and climate change. Études/Inuit/Studies 34: 151-165.

Fenge, T. 2003. POPs and Inuit: influencing the global agenda. In D. L. Downie and T. Fenge (eds.) Northern lights against POPs: combatting toxic threats in the Arctic. Montreal and Kingston: McGillQueens Press. Pp. 192-213.

Gibson-Graham, J.K. 2006. A post-capitalist politics. Minneapolis: University of Minnesota Press.

Gibson-Graham, J.K. 2006[1996]. The end of capitalism (as we knew it): a feminist critique of political economy. Minneapolis: University of Minnesota Press.

Gibson-Graham, J.K. and G. Roelvink. 2009. An economic ethics for the Anthropocene. Antipode. 41:320346.

Gombay, N. 2010a. Making a living: place, food, and economy in an Inuit community. Saskatoon, Manitoba: Purich Publishing.

Gombay, N. 2010b. Community, obligation, and food: lessons from the moral geography of Inuit. Geographiska Annaler: Series B: 237-250.

Hamblyn, R. 2009. The whistleblower and the canary: rhetorical constructions of climate change. Journal of Historical Geography 35(2): 223-236.

Harder, M.T., and G.W Wenzel. 2012. Inuit subsistence, social economy and food security in Clyde River, Nunavut. Arctic 65: 305-318.

Harper, K. 1986. Give me my father's body: the life of Minik, the New York Eskimo. New York: Washington Square Press.

Henderson, A. 2007. Nunavut: rethinking political culture. Vancouver: University of British Columbia Press.

Ingold, T. 2000. The perception of the environment: essays in livelihood, dwelling and skill. London and New York: Routledge.

Ingold, T. 2008. Anthropology is not ethnography. Proceedings of the British Academy 154:69-92.

Kafarowski, J. 2009. Gender, culture and contaminants in the North. Signs: Journal of Women in Culture and Society 34: 494-499.

Kral, M.J., L. Idlout, J.B. Minore, R.J. Dyck and L.J. Kirmayer. 2011. Unikkaartuit: meanings of well-being, unhappiness, health, and community change among Inuit in Nunavut, Canada. American Journal of Community Psychology 48: 426-38.

Kramer, S., S.M. Hikel, K. Adams, D. Hinds and K. Moon. 2012. Current status of the epidemiologic evidence linking polychlorinated biphenyls and non-Hodgkin lymphoma and the role of immune dysregulation. Environmental Health Perspectives 120: 1067-1075.

Krupnik, I. and D. Jolly (eds.) 2002. The earth is faster now: indigenous observations of Arctic environmental change. Fairbanks, Alaska: Arctic Research Consortium of the United States.

Latour, B. 2004. How to talk about the body? The normative dimension of science studies. Body and Society 10: 205-229.

Laugrand, F. and J.G. Oosten. 2009. Transfer of Inuit qaujimajatuqangit in modern Inuit society. Études/Inuit/Studies 33(1-2): 115-152. 
Mazzarella, W. 2009. Affect: what is it good for? In S. Dube (ed). Enchantments of modernity: empire, nation, globalization. New Delhi and Abington: Routledge. Pp. 291-309.

Mauss, M. 1990(1924). The gift: The form and reason for exchange in archaic societies. London: Routledge.

Natcher, D.C. 2009. Subsistence and the social economy of Canada's aboriginal north. The Northern Review 30: 83 - 98.

Navaro-Yashin, Y. 2009. Affective spaces, melancholic objects: ruination and the production of anthropological knowledge. Journal of the Royal Anthropological Institute 15: 1-18.

Navaro-Yashin, Y. 2012. The make-believe space: affective geography in a postwar polity. Durham, NC: Duke University Press.

Plumwood, V. 2002. Environmental culture: the ecological crisis of reason. London and New York: Routledge.

Raffles, H. 2002. Intimate knowledge. International Social Science Journal 54: 325-35.

Rasing, W.C.E. 1994. "Too many people": order and nonconformity in Iglulingmiut social process. Nijmegen: Katholieke Universiteit.

Restakis, J. 2006. Defining the social economy: the British Columbia context. Paper prepared for the British Columbia Social Economy Roundtable, January 2006.

Richard, A. and D. Rudnyckyj. 2009. Economies of affect. Journal of the Royal Anthropological Institute 15: 57-77.

Roelvink, G. 2010. Collective action and the politics of affect. Emotion, Space and Society 3: 111-118.

Rusiecki, J.A., A. Baccarelli, V. Bollati, L. Tarantini, L.E. Moore and E.C. Bonefeld-Jorgensen. 2008. Global DNA hypomethylation is associated with high serum-persistent organic pollutants in Greenlandic Inuit. Environmental Health Perspectives 116: 1547-1552.

Searles, E. 2010. Placing identity: town, land, and authenticity in Nunavut, Canada. Acta Borealia 27: 151166.

Seigworth, G.J., and M. Gregg. 2010. An inventory of shimmers. In M. Gregg and G.J. Seigworth (eds.) The affect theory reader. Durham: Duke University Press. Pp. 1-25.

Shearer, R. and S.L. Han. 2003. Canadian research and POPs: the Northern Contaminants Program. In D.L. Downie and T. Fenge (eds.) Northern lights against POPs: combatting toxic threats in the Arctic. Montreal and Kingston: McGill-Queens Press. Pp. 41 - 59.

Stairs, A. and G.W. Wenzel. 1993. "I am I and the environment": Inuit, community and identity. Journal of Indigenous Studies 3(1): 1-12.

Sullivan, P. 2008. Bureaucratic process as Morris Dance: an ethnographic approach to the culture of bureaucracy in Australian aboriginal affairs administration. Critical Perspectives on International Business 4(2/3): 127-141.

Takano, T. 2005. Connections with the land: land-skills courses in Igloolik, Nunavut. Ethnography 6: 463486.

Watt-Cloutier, S. 1998. Plenary intervention in Montreal, Canada, at the first meeting of the InterGovernmental Negotiating Committee Toward a Global Convention on Persistent Organic Pollutants [Accessed 2/4/13]. http://inuitcircumpolar.com/index.php?ID=110\&Lang=En

Watt-Cloutier, S. 1999. Plenary intervention in Nairobi, Kenya, at the second meeting of the InterGovernmental Negotiating Committee Toward a Global Convention on Persistent Organic Pollutants [Accessed 2/4/13]. http://inuitcircumpolar.com/index.php?ID=109\&Lang=En

Watt-Cloutier, S. 2001. Speech given by Ms. Sheila Watt-Cloutier at the Indigenous Peoples Plenary Intervention. [Accessed 1/07/2014]. http://inuitcircumpolar.com/index.php?auto_slide=\&ID=96\&Lang=En\&Parent_ID=\&current_slide_n $\underline{\mathrm{um}}=$

Watt-Cloutier, S. 2002. Presentation by Ms. Sheila Watt-Cloutier to the Deputy Ministers and Assistant Deputy Ministers of the Nunavut Government [Accessed 2/4/13]. 
http://inuitcircumpolar.com/index.php?Lang=En\&ID=92\&printable=1\&Nav=\&Action=\&Action2=\& Report=\&Report Text=\&Record=\&Record2=\&Record3=\&addnew $=$

Watt-Cloutier, S. 2007. Testimony before IACHR on global warming and human rights. [Accessed 2/4/13]. http://earthjustice.org/sites/default/files/library/legal_docs/testimony-before-iachr-on-global-warminghuman-rights-by-sheila-watt-cloutier.pdf

Wenzel, G.W. 1995. Ningiqtuq: resource sharing and generalized reciprocity in Clyde River, Nunavut. Arctic Anthropology 32:43-60.

White, G. 2006. Cultures in collision: traditional knowledge and Euro-Canadian governance processes in northern land-claims boards. Arctic 59(4): 401-414.

Wilson, E.O. 1984. Biophilia: the human bond with other species. Cambridge: Harvard University Press. 